\title{
テラヘルツ光によるエラストマー中の 配合剂分散非破壊評価法の開発 \\ Development of Nondestructive Evaluation Method of Additives Dispersion Inside Elastomers by Terahertz Radiation
}

\author{
平川靖 之* \\ (Received on January 25, 2017)
}

\section{1. は じめ に}

テラヘルッ (Terahertz, THz) という言葉は, 最近少 しずつ新聞やテレビでも聞かれるようになってきたもの の，まだ一般的に使われる状況になっているとは言いがた い. $\mathrm{THz}$ とは, 電磁波の周波数の単位を表している。 $\mathrm{THz}$ 帯もしくはTHz 領域は, 電波より周波数が高く, 可 視光・赤外線より周波数が低い電磁波領域のことを指す. この領域の電磁波は, 電波のように金属以外の物質をよく 透過し，光のようにレンズや鏡により取り回すことができ る.つまり，電波と光の両方の特性を併せ持っているとい うことができる. THz 領域の電磁波（以下, $\mathrm{THz}$ 光と呼 ぶ）の発生・検出は, この 20 年間のフェムト秒レーザー 技術の発展にともない急速に発達し，現在あらゆる分野に おけるテラヘルッ関連の研究が活発に進められている ${ }^{1,2)}$.

我々, 久留米高専の研究グループでは, $\mathrm{THz}$ 光を使っ た分光法の一つである $\mathrm{THz}$ 時間領域分光法によるエラス トマーの非破壊迅速分析・評価への応用研究をすすめてい る. 本稿では, $\mathrm{THz}$ 光の基本, 時間領域分光法をまず簡 単に解説し, 本法をエラストマー評価に応用して得られて いる成果を配合剂分散評価を中心に説明する。

\section{2. 原理}

\section{2. $1 \mathrm{THz}$ 光}

THz光は前述したように電磁波の一種で, Figure 1に 示す電波（マイクロ波）と光（赤外線）の境界に当たる周 波数帯の電磁波のことである. 厳密な周波数領域は定義さ れていないようであるが, $0.1 〜 10 \mathrm{THz}$ (波長 $30 \sim 3000$ $\mu \mathrm{m} ）$ の領域のことを示すことが多い.この領域の電磁波 は, 光と電波の両方の特性を併せ持っており, X線のよう

*久留米工業高等専門学校 電気電子工学科 - 教授 （８８30-8555 福岡県久留米市小森野 1-1-1）
な物質の透過性を持つと同時に, 光のようにレンズ等の光 学素子によりコントロールできる．X線と比較すると， 1 光子当たりのエネルギーが 4 桁以上小さいため, 原理的に 測定対象物を破壊する可能性が格段に低い点も特徵であ る. また, 水分子のような極性分子に対しては強く吸収さ れ，金属には反射される性質がある．この周波数帯は分光 学的には, 分子の回転運動 (気体), 分子の回転緩和や秤 動運動（液体），フォノンや分子間振動（固体）がエネル ギー的に該当し，アミノ酸などの有機物結晶では指紋スペ クトルを示すものもある. 分子構造によりスペクトルが変 化するため, 光学異性体などの異性体の検出も報告されて いる ${ }^{2,3)}$. 指紋スペクトルについては, 理化学研究所と情 報通信研究機構が共同でインターネットにデータを公開し ており，誰でも利用できるようになっている（http:// www.riken.jp/THzdatabase/).

$\mathrm{THz}$ 光の応用は, 古くは天文学の観測手法を始めとし て, 最近は, 空港等におけるセキュリティチェックでの利 用があげられる，現在商品化されている装置は， THz 領 域として見ると周波数が若干低いものの, ミリ波全身スキ ヤナとして海外では導入済みの空港もある. 国内では運用 評価試験を終え, 順次主要空港から導入すると国土交通省 が発表している ${ }^{4)}$. この他, 爆発物等危険物や禁止薬物の 検出が報告されている ${ }^{5)}$ 他, 薬品の結晶多形の分析 ${ }^{6)}$, 塗 膜評価への応用 ${ }^{7}$ も提案されている. 以上の分析的な応用 に加え, 高速通信への応用(搬送波としてTHz光を利用 する）研究も進められている ${ }^{2,8)}$.

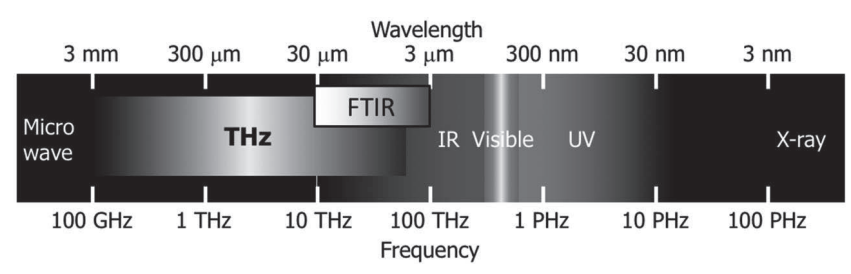

Figure 1 Electromagnetic region of $\mathrm{THz}$ band. 


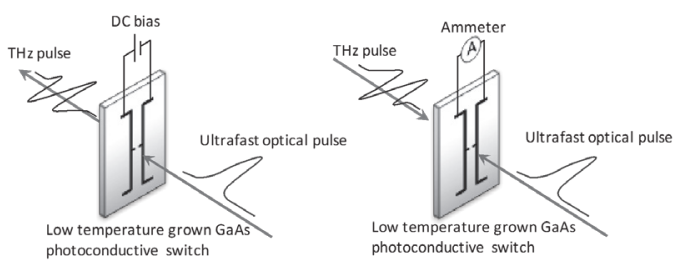

Figure $2 \mathrm{THz}$ generation (left) and $\mathrm{THz}$ detection (right) by photoconductive switch.

$\mathrm{THz}$ 光発生・検出法については, 本稿の主題から逸れ るので，簡単な説明にとどめたい，主なものとして，半導 体もしくは非線形光学結晶（有機，無機）にレーザー光を 入射することで発生させる手法と, 自由電子レーザー, 量 子カスケードレーザーがあげられる ${ }^{2)}$. 本稿で説明する実 験で利用した発生法は, Figure 2 に示す光伝導（Photoconductive, PC) スイッチもしくは4-dimethylamino-N-methyl-4-stilbazolium tosylate（DAST）結晶にパルス幅がフ エムト秒の超短パルスレーザー光を入射することで発生さ せる手法である。DAST 結晶を利用した方が，広带域， 高出力な $\mathrm{THz}$ 光発生に適している。一方, $\mathrm{THz}$ 光の検出 については，発生に利用するのと同じPCスイッチ，電気 光学効果サンプリング, ボロメーター, 焦電素子などが代 表的なものとしてあげられるが2 ${ }^{2}$, 本研究では構成が単純 で使い勝手の良い $\mathrm{PC}$ スイッチを利用した. $\mathrm{THz}$ 光が $\mathrm{PC}$ スイッチに入射したときに，励起レーザー光を照射すると $\mathrm{THz}$ 光強度に応じてキャリア電流が発生する。これを信 号として検出するものである.

\section{2. $2 \mathrm{THz}$ 時間領域分光法}

以上のような新しい THz 光源を利用した分光法として は, $\mathrm{THz}$ 時間領域分光法 ( THz Time-Domain Spectroscopy，THz-TDS） 9-11) を代表的なものとしてあげること ができる．本手法の特徴は， THz光の実時間波形を計測 することで，クラマース・クローニッヒの関係式（実数部 と虚数部を結びつける理論式）を使うことなく, 複素屈折 率を始めとする様々な物性值を求めることができる点にあ る。すすなわち，実時間波形をそのまま単純にフーリエ変換 することで振幅スペクトルと位相スペクトルを算出でき, それらを基に透過率, 吸収率, 反射率, 複素屈折率を始め とする複素物性值を求めることができる，典型的な装置構 成をFigure 3 に示す，基本波光源であるフェムト秒レー ザー光を二つに分離し，一方を $\mathrm{THz}$ 光発生用に，他方を $\mathrm{THz}$ 光検出用とする。本構成図では DAST 結晶を $\mathrm{THz}$ 光 源としている. 発生した THz 光をレンズとミラーで試料 に集光し，透過してきた THz 光を検出用のPCスイッチに 導き, タイミングを合わせて最初に分離していた $\mathrm{THz}$ 光 検出用のフェムト秒レーザー光を入射し, THz 信号とし てキャリア電流を検出する。この際，ノイズを抑えるため に前置増幅器やロックイン増幅器が利用される。本研究で

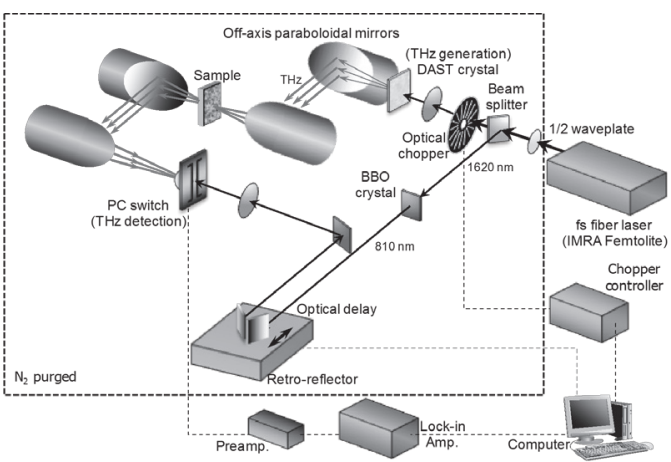

Figure 3 Configuration of THz-TDS system.

は, 主に透過計測を行い, 吸光度として物性を評価した。 その際の解析に使うフーリエ変換は以下の式で与えられる.

$$
E(\omega)=\frac{1}{2 \pi} \int_{-\infty}^{\infty} E(t) e^{i \omega t} d t=|E(\omega)| e^{i \phi(\omega)}
$$

ここで, $E$ は電界, $\phi$ は位相， $\omega$ は角周波数， $t$ は時間を示 す，実際の計算では，高速フーリ工変換（FFT）が使わ れることが多いが, 近年はPCの処理速度が上がったため, 離散フーリエ変換（DFT）で処理されることもある，試 料がある場合とない場合の電界をそれぞれ $E_{\text {sample }}(\omega)$, $E_{r e f}(\omega)$ とすると, 透過率 $T(\omega)$ と位相差 $\Delta \phi(\omega)$ は以下 のように表すことができる.

$$
\begin{aligned}
& T(\omega)=\left|\frac{E_{\text {sample }}(\omega)}{E_{\text {ref }}(\omega)}\right|^{2} \\
& \Delta \phi(\omega)=\phi_{\text {sample }}(\omega)-\phi_{\text {ref }}(\omega)
\end{aligned}
$$

これらを使うと, 複素透過率 $\tilde{t}(\omega)$ は

$$
\tilde{t}(\omega)=\sqrt{T(\omega)} e^{-i \Delta \phi(\omega)}
$$

と与えられる. 複素屈折率を $\tilde{n}(\omega)=n(\omega)-i \chi(\omega)$ と置 くと, 複素透過率 $\tilde{t}(\omega)$ は試料の厚みを $d$, 光速を $c$ として $\tilde{t}(\omega)=\frac{2}{\tilde{n}+1} \frac{2 \tilde{n}}{\tilde{n}+1} e^{-i \frac{(\tilde{n}-1) d \omega}{c}}$

と理論的に求まるため, これら二つの複素透過率 $\tilde{t}(\omega)$ の 式の比較から複素屈折率を算出できることになる ${ }^{2)}$.なお， 本稿で多用する吸光度 $A(\omega)$ は,

$$
A(\omega)=-\log _{10} T(\omega)
$$

として求まるが, 試料の厚みに依存するため, 単位厚み $(1 \mathrm{~cm})$ 当たりに換算して表示することとした.

\section{THz-TDSによる評価実験}

我々の研究グループでは, THz-TDSを用いたエラスト マー非破壊評価を試みており, 特に配合剤分散評価に力を 入れている. 実験では, THz-TDSシステムとして, 自作 のシステムと市販製品システムの両方を用いている. 自作 システムは, 基本波光源のフェムト秒レーザーとして, フ 
エムト秒ファイバーレーザー（IMRA， Femtolite C-20,

$780 \mathrm{~nm}, 100 \mathrm{fs}, 20 \mathrm{~mW}$ ) を用いた, 透過計測専用のシ ステムで, $\mathrm{THz}$ 光源は PCスイッチである，外観を Figure 4（a）に示す. 一方，市販のシステム（大塚電子, TR100KS, Figure 4 (b)) は, 高出力フェムト秒ファイバー レーザー（IMRA, Femtolite HX-150, 1620 nm, 100 fs, $200 \mathrm{~mW}$ ）を基本波レーザーとするシステムで，構成は Figure 3 の通りのDAST 結晶を利用したものとなってい る. また，透過計測，反射計測の両方に対応している.

以下に，これまで得られている結果を説明するが，配合 剤に関する計測の殆どは自作システムで，それ以外につい ては市販システムによる実験結果である.

\section{1 ポリマーの評価}

THz-TDSによるエラストマーの評価を行うにあたり， まずベースのポリマーについて $\mathrm{THz}$ 領域における透過特 性を評価した。代表的な天然ゴム (NR), ブタジエンゴム $(\mathrm{BR})$ ，スチレンゴム $(\mathrm{SBR})$ ，ニトリルゴム $(\mathrm{NBR})$ ，エ チレンプロピレンゴム $(\mathrm{EPDM})$ を試料に選んだ。そのう ちのNBR, SBR, NRの結果をFigure $5^{12)}$ に示す。それぞ れ試料台に設置できる寸法に切り出し計測を行ったが，厚 みを統一できなかったため, 単位厚み（1 cm）当たりの 吸光度として評価した。いずれのポリマーも複数回計測を 行ったが，NRについては，天然由来のために安定した吸 光度スペクトルを得ることが難しかった．最初の原理で触 れたように，THz光は極性分子に吸収される特性を有す るが，ポリマーにおいてもその特性が反映されることが本 実験で確認された，すなわち，極性ゴムとして知られる NBRの吸光度スペクトルは, 他のポリマーよりも吸光度

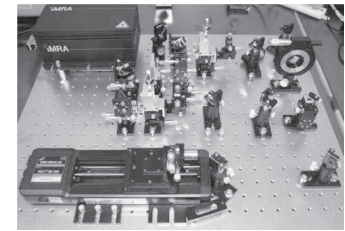

(a)

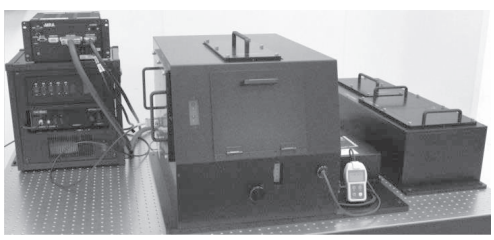

(b)

Figure 4 THz-TDS systems used in the study, (a) homemade system, and (b) commercial system.

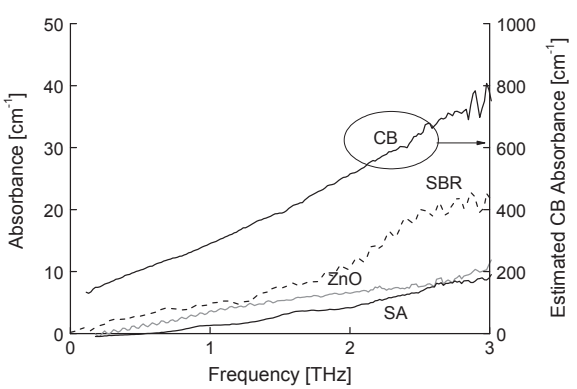

(a)
が大きく評価されていることが見て取れる，本傾向は安定 して観察された。 なお，ポリマー単体では，結晶性構造を 有しているわけではないため, 特徵的な鋭い吸収ピークは 観察されなかった。

\section{2 配合剤の評価}

ベースのポリマーに引き続き, 配合剂について同様に $\mathrm{THz}$ 吸光度スペクトル計測を行った。 代表的なフィラー であるカーボンブラック（CB，東海カーボン SEAST 3), 加硫促進助剤の酸化亜鉛, ステアリン酸, 加硫剤の硫黄 (S), 加硫促進剂のCBS, MBTS, TMTDを試料として取 り上げた。 なお, 加硫促進剂は本研究グループで多用して いるものを選定した. Figure $6^{12)}$ にそれぞれの配合剤の 吸光度スペクトルを SBR ポリマー単体の吸光度スペクト ルとともに示す. CBは一見 $\mathrm{THz}$ 吸収が非常に大きいよう に見えるが，実際には，その金属的な性質により THz光 を反射する結果, $\mathrm{THz}$ 光を透過できず, 見かけ上 $\mathrm{THz}$ 吸 収が大きく評価されていることが分かっている．また，加 硫系薬剤を含まない $\mathrm{A}$ 練りの段階で配合される（a）の加 硫促進助剂には，顕著なスペクトル構造が見られない。一 方, B練り行程で配合される（b）の加硫剤, 加硫促進剂 では，鋭いスペクトルが観察されることが分かる。

以上の配合剂の $\mathrm{THz}$ 吸光度スペクトルから， CBはその 大きな見かけの吸収のため, THz光により検出が容易で あることが期待できる。

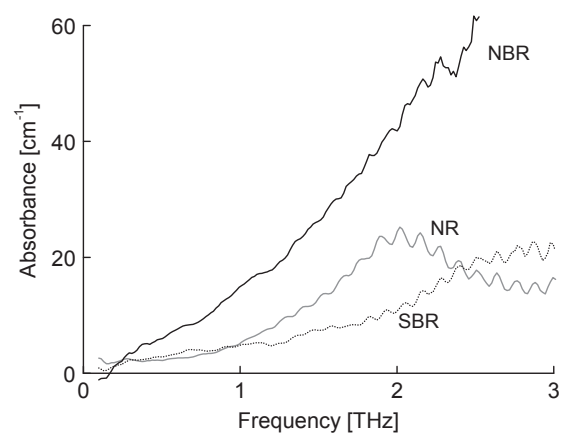

Figure $5 \mathrm{THz}$ absorbance spectra for various crude polymers, NR, SBR, and NBR

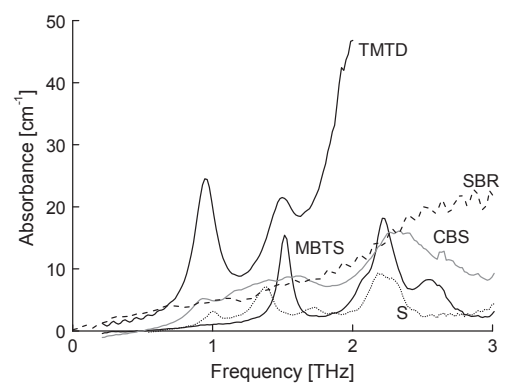

(b)

Figure $6 \mathrm{THz}$ absorbance spectra for various additives, (a) $\mathrm{CB}$, zinc oxide $(\mathrm{ZnO})$ and stearic acid (SA), and (b) vulcanizing agent and vulcanization accelerators. 


\section{3 配合剂分散評価への応用}

$\mathrm{THz}$ 領域において， CBの検出が容易であることが，そ の吸光度スペクトルから予想されたため, その分散評価の 準備として，THz吸光度スペクトルの CB配合量依存性を 計測した。試料には，NBR加硫ゴムを用いた。結果を Figure 7 に示すが，CB配合量が5，20，40 phr と増大す るにつれ，吸光度もそれに応じて増大していることが分か る. 加えて, Figure 6に示された他の配合剤の吸光度の影 響がないかを簡易的に $\mathrm{THz}$ 吸光度スペクトル上で確認し たのがFigure 8である。図中の実線が実験で得られた吸 光度スペクトルで，破線がFigure 6 に示された各種配合 剂をその配合量に応じて加算した結果得られたスペクトル である。配合比率は, NBR 100 phr, CB 40 phr, ZnO 5 phr, ステアリン酸, 硫黄, CBS, MBTS, TMTDはそれ ぞれ $1 \mathrm{phr}$ とした。加硫時の高温・高圧により各種配合剂 が室温時のままであるとは限らないが, その配合量は NBR ポリマーとCBに比べると微々たるものであり,この 計算上でも全く影響がないことが確認できる，更に実験に おいても，(データは示していないが）CBのみを配合しな いNBR加硫ゴムの $\mathrm{THz}$ スペクトルは, NBRポリマーのみ のスペクトルとほぼ一致することを確認した．以上の結果 から, 吸光度が $\mathrm{CB}$ 配合量に比例していない問題点が本実 験データではあるものの，エラストマー中のCB分散を相 対的に $\mathrm{THz}$ 光で評価できる可能性が示された.

そこで, 引き続き, 寸法 $120 \mathrm{~mm} \times 120 \mathrm{~mm}$ の加硫ゴム 中の任意の 4 点における $\mathrm{CB}$ 吸光度に大きな差異があるこ とを確認した ${ }^{13,14)}$ 。その後, 引張試験機（A\&D, RTG1310）で破断したゴム試料の破断面付近を THz 分光によ り CB 分散状況を確認することを試みた ${ }^{15)}$ 。試料は，ポリ マーの吸光度の影響を抑えられるSBR加硫ゴム（温度 150 ${ }^{\circ} \mathrm{C}$, 圧力 $10 \mathrm{MPa}$ にて加硫）とし, JIS ダンベル状 3 号型で 切り出した厚み約 $2 \mathrm{~mm}$ の引張試験用試料が, 引張試験に より断裂した状態のものである。実験では, 断裂箇所周辺 の $20 \mathrm{~mm}$ 程度の部位を厚み約 $1 \mathrm{~mm}$ に加工した後に $\mathrm{THz}$

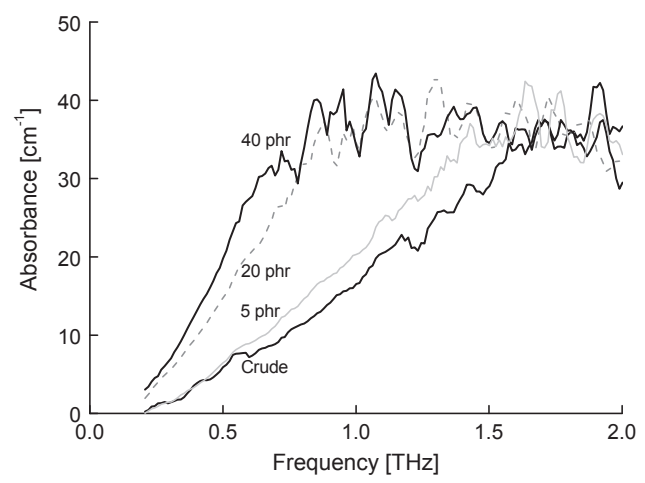

Figure $7 \mathrm{THz}$ absorbance spectra of NBR vulcanized rubbers with various $\mathrm{CB}$ compounding amounts, $0,5,20$ and 40 phr.
光でスキャンし, $\mathrm{THz}$ 吸光度スペクトルを求めた。分散 イメージング構築には, 各計測点の $\mathrm{THz}$ 吸光度スペクト ルを周波数に関して積分して得られる值を吸収の代表值と して処理した。実験結果の一例を Figure 9 に示す。これ は, CB 1 phr配合の試料の結果を示したもので, イメー ジングに使用した $\mathrm{THz}$ 吸光度スペクトルの周波数域は 0.6 〜 $2 \mathrm{THz}$ ある. 図中では, $\mathrm{THz}$ 吸光度の大きな部分は黒 に近い色で示されているが, $\mathrm{THz}$ 吸光度が大きいほど $\mathrm{THz}$ 光が試料を通り抜けてこないので, $\mathrm{CB}$ が多く分布す ることを意味する．興味深いことに，断裂部周辺は $\mathrm{THz}$ 吸光度が小さいことを示す白に近い色を示しており， CB の分布が少なくなっていることを示唆している. フィラー である CBは補強効果があると言われているが，本結果は それを人間の目に見える形で示したことになる。しかしな がら，本結果に疑問点もある。それは， $\mathrm{CB}$ の分布が少な い箇所が引っ張られることで断裂したのか, それとも引っ 張られたことにより CBの分布が変化して CBが少なくな り, その結果断裂したのかが分からない点である。この点 は，我々自身も非常に興味のあるところであるため，試料 を引っ張っている状態で $\mathrm{THz}$ 計測が行えるように装置を 改良して，現在実験を進めている。 また，Figure 7のよう に, $\mathrm{CB}$ 配合量に対して THz 吸光度が比例関係にないよう に見える点については，以下のことが明らかとなってい る. 即ち, $\mathrm{CB}$ が高配合時には比例関係から外れものの,

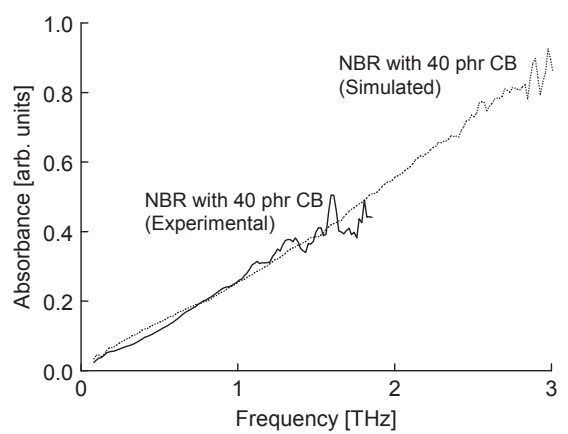

Figure 8 Comparison of the experimental $\mathrm{THz}$ spectrum of the NBR sample contained $40 \mathrm{phr} \mathrm{CB}$ and calculated $\mathrm{THz}$ absorbance spectrum of NBR sample based on additives' absorbance data shown in Figure 6 and their compounding ratio.

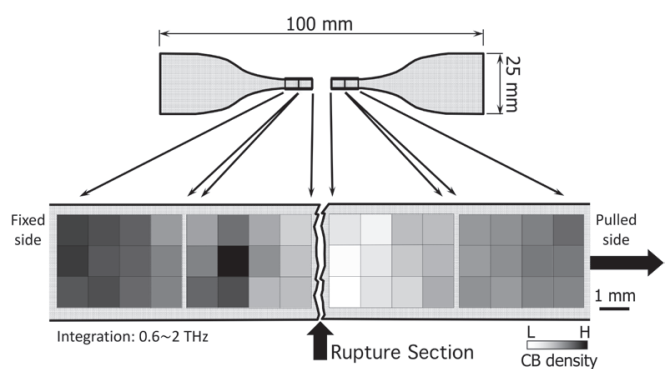

Figure $9 \mathrm{THz}$ imaging of $\mathrm{CB}$ distribution around rupture section of tensile-tested sample. The $\mathrm{CB}$ compounded amount was $1 \mathrm{phr}$. 
Figure 9の試料のような低配合量では, $\mathrm{THz}$ 吸光度と $\mathrm{CB}$ 分布はほぼ比例関係にあると考えて良いことが分かってい る $^{16)}$.

\section{4 その他の特性評価の可能性}

本稿は，配合剂の分散評価に焦点を合わせ，特に興味が もたれている $\mathrm{CB}$ 分散について, $\mathrm{THz}$ 光による評価の可能 性について説明を行ってきた。 ここでは, CB 分散評価以 外の加硫反応の可視化, 及び $\mathrm{A}$ 練り評価の可能性につい て，これまでに得られている実験結果を紹介する.

（1）加硫反応可視化の可能性

加硫反応では，架橋点においてポリマーが結合し，エラ ストマー内に網目構造が広がっていくと考えられている. この様子が $\mathrm{THz}$ 光により可視化できないか試みた，実験 結果の一例を Figure 10 ${ }^{17)}$ に示す. CBの強い（見かけ上 の） $\mathrm{THz}$ 吸収の影響を取り除くため，CBを配合しない BR コンパウンドを用いて加硫を行った。まず加硫試験機 により，本試料の最適加硫時間 T 90 は事前に 21 分 30 秒で あることを確認した。そして，T90を基に決定した複数の 加硫反応時間における試料は, 加硫用モールドから所定の 時間に取り出しすぐに氷水に浸し, 反応を停止させること で用意した. Figure 10 の THz 吸光度イメージは, Figure 9 と同様に黒い色ほど $\mathrm{THz}$ 吸光度が大きいことを示してい るが，これはCBの影響によるものではない，T90の直前 に THz吸光度が下がり（白っぽくなり），その後また吸光 度が増大する（黒くなる）ことが分かる。また，T90後は $\mathrm{THz}$ 吸光度の分布も均一化していくように見える。これ

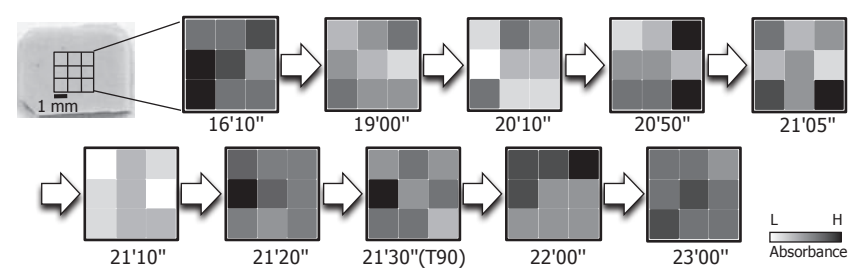

Figure 10 Temporal change of $\mathrm{THz}$ absorbance image with progress of vulcanization reaction. The sample contained no $\mathrm{CB}$.

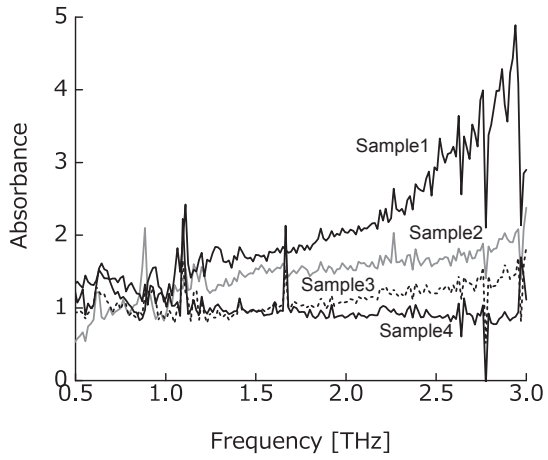

(a)
は, 加硫反応が試料のあちこちで起こり始め（THz 吸光 度の不均一), 徐々に反応が試料全体に広がっている様子 を反映しており，結果として THz 吸光度が均一化してい っているものと考えるのが妥当であろう。この様子がよく 分かるように, 試料内の計測箇所 9 点の $\mathrm{THz}$ 吸光度の大き さと, 吸光度分布の標準偏差をグラフ化したのが, Figure 11 である.この変化の傾向は再現性が見られることから， 加硫反応に伴う何らかのエラストマー内部の変化を反映し ていると考えている，我々のグループでは，電流計測によ る加硫反応評価も試みており, 加硫反応の進展に伴い電気 抵抗（インピーダンス）が減少し, やがて一定に落ち着く ことを見いだしている。電気抵抗（インピーダンス）の低 下は，単純な電気回路では並列回路の増大で実現できるた め, 加硫反応に伴う網目構造の進展が, 電気的には並列回 路の構築に相当していると考えることもできる. また，こ の網目構造は, 光学的に $\mathrm{THz}$ 光と干渉する可能性もあり, これらの影響でFigure 10，11の結果が得られている可能 性もあるが, 現時点では明確な原因は特定できていない.

(2) 練り評価の可能性

A 練りの善し悪しを客観的に評価するのは一般的に困難 であるが, THz-TDSで評価できる可能性のあることを示

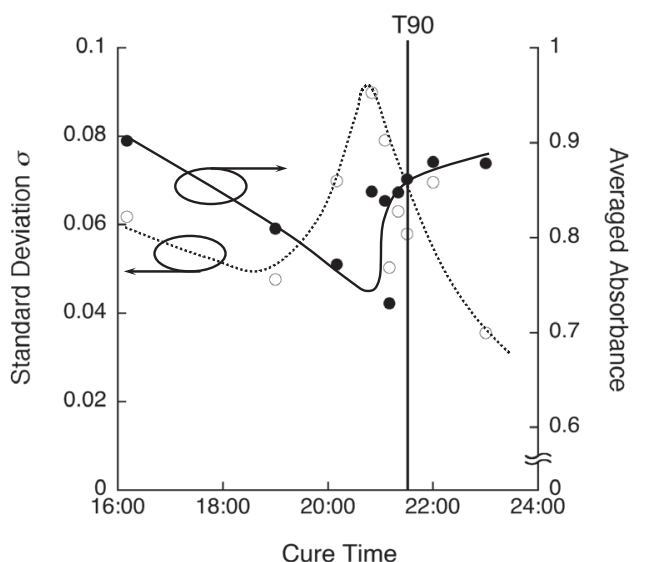

Figure 11 Temporal change of $\mathrm{THz}$ absorbance intensity (solid line) and intensity dispersion (standard deviation $\sigma$, dotted line) with progress of vulcanization reaction.

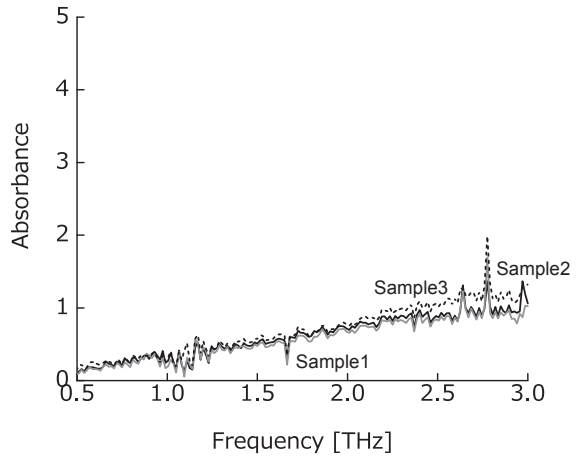

(b)

Figure 12 Evaluation of $\mathrm{THz}$ absorbance spectra of A-mixed samples. (a) A-mixed samples by 200 open-rolled mixing at room temperature, and (b) the same batch samples with additional 400 open-roll mixing at $80{ }^{\circ} \mathrm{C}$. 
したのが, Figure 12である. 図（a）は4インチのオープ ンロール (室温) で200回 A 練りした BRベースの試料の $\mathrm{THz}$ 吸光度スペクトルを任意の 4 点を計測したものであ る. 全てのスペクトルに相関性が見られず，非常にバラッ キの大きな状態にあることが一目瞭然である。一方，（b) は同じ試料を更に $80^{\circ} \mathrm{C} て ゙$ 同じロール機で 400 回追加して練 ったものである．任意の3点しか計測していないが，(a) のスペクトルのバラツキ状態とは比較にならないほど，均 一になっていることが一目で分かる. 試料はTHz-TDS シ ステムで計測が可能になるように，A練り直後のものから 数グラムの小片を切り出し，それをプレス機で成形しただ けである。このように, THz-TDSでは試料の前処理を行 うことなく, 通常の手法では評価の難しいA 練りの練り 上がり状態評価も可能であることを示唆している.

\section{4. ま め}

THz-TDSを利用したエラストマー評価に関連して，配 合剂分散評価及びそのほかの特性評価について，これまで に得られている実験結果とともに紹介した。まだ，開発途 上の手法であるため, 様々な改善すべき点が点在し, 実証 が不十分でもあるが, 従来の手法では難しかった分散状況 を簡易に非破壊評価が行うことができるのは，非常に魅力 的な特徴であるといえる。 また，加硫反応や練りの状態評 価など，興味深い応用の可能性も示唆されており，これか らの研究の進展が待ち望まれる。なお，ここで説明した実 験結果は全て透過計測に基づくものであるが，反射計測に 依れば，高 CB配合の試料でも，表面付近の分散状況を正 確に把握できる可能性のあることが実験的に確認されてい ることを最後に付け加えさせていただく.

\section{謝辞}

本研究を進めるに当たり多大なご支援を頂いた大阪大学 斗内政吉教授に心から深謝致します。また, $\mathrm{THz}$ システ ム構築にご協力頂いたアイシン精機株式会社 廣住知也様, 大竹秀幸博士に感謝致します。試料作製, $\mathrm{THz}$ 計測の解 釈や研究の指針についてご助言，ご協力頂いた久留米工業 高等専門学校 森 哲夫名誉教授, 権藤豊彦博士, 神野拓也 技術職員，ならびに研究をともに行った学生諸君に御礼申 し上げます。本研究の一部は，JSPS科研費 24560056 およ び第 23 回財団法人 江野科学振興財団研究助成の支援を受 け執り行われました。

\section{References}

1) Tonouchi, M.: Nature Photonics, 1, 97 (2007)

2 ) Tonouchi, M. Supervised: “Tera-Herutu Gijyutu”, Tera-Herutu Tekunoroji-DoukouChousa iinkai Ed., Ohmu-Sya, Tokyo, chapter 1 (2006)

3 ) Kitakishi, K.: "Tera-Herutu Ha Shin Sangyo", Tonouchi, M. Ed., CMC Syuppan, Osaka, p.211 (2011)

4 ) http://www.mlit.go.jp/report/press/kouku09_hh_000078.html

5 ) Otani, C.: "Tera-Herutu Ha Shin Sangyo", Tonouchi, M. Ed., CMC Syuppan, Osaka, p.149 (2011)

6 ) Zeitler J. A.; Rades T.; Taday P. F.: In "Terahertz Spectroscopy", S. L. Dexheimer Ed., CRC Press, Boca Raton, p.299 (2008)

7 ) Takayanagi, J.; Ohtake, H.: Shikizai Kyokaishi, 85, 459 (2012)

8 ) Nagatsuma, T.: “Tera-Herutu Ha Shin Sangyo", Tonouchi, M. Ed., CMC Syuppan, Osaka, p.238 (2011)

9 ) Hangyo, M.: “Tera-Herutu Ha no Kiso to Oyo”, Nishizawa, J. Ed., Kogyochosakai, Tokyo, p.231 (2005)

10) Nishizawa, S.: In “Terahertz Optoelectronics”, Sakai, K. Ed., Springer-Verlag, Heidelberg, p.203 (2005)

11) Baxter, J. B.; Schmuttenmaer, C. A.: IN “Terahertz Spectroscopy”, Dexheimer, S. L. Ed., CRC Press, Boca Raton, p.73 (2007)

12) Hirakawa, Y.; Ohno, Y.; Gondoh, T.; Mori, T.; Takeya, K.; Tonouchi, M.; Ohtake, H.; Hirosumi, T.: J. Infrared, Millimeter and Terahertz Waves, 32, 1457 (2011)

13) Hirakawa, Y.; Ohno, Y.; Gondoh, T.; Mori, T.; Takeya, K.; Tonouchi, M.; Ohtake, H.; Hirosumi, T.: Extended Abstracts of 2nd International Workshop on Terahertz Technology (Teratech 2009), 271 (2009)

14) Hirakawa, Y.; Ohno, Y.; Gondoh, T.; Mori, T.; Takeya, K.; Tonouchi, M.; Ohtake, H.; Hirosumi, T.: Proceedings of the 35th International Conference on Infrared, Millimeter, and Terahertz Waves (IRMMW-THz 2010), Mo-P.30 (2010)

15) Hirakawa, Y.; Ohno, Y.; Gondoh, T.; Mori, T.; Takeya, K.; Tonouchi, M.; Ohtake, H.; Hirosumi, T.: Extended Abstracts of International Symposium on Terahertz Nanoscience (TeraNano 2011), 219 (2011)

16) Hirakawa, Y.; Kamino, T.; Gondoh, T.; Hirano, S.; Noguchi, T.: Abstracts of Energy, Materials and Nanotechnology Meeting on Terahertz 2016, 77 (2016)

17) Hirakawa, Y.; Nobutsuka, A.; Gondoh, T.; Mori, T.: Extended Abstracts of The Second International Symposium on Frontiers in THz Technology (FTT2015), Pos2.33 (2015)

\section{日本語表記参考文献}

2 ）斗内政吉監修：テラヘルッ技術，テラヘルッテクノロジー動向 調查委員会編，オーム社，東京，1章（2006）

3 ) 北岸恵子：テラヘルツ波新産業, 斗内政吉監修, ジーシーエム 出版, 大阪, p.211 (2011)

4) http://www.mlit.go.jp/report/press/kouku09_hh_000078.html （国土交通省報道発表資料「先進的なボデイスキャナー運用評価 試験 結果概要」)

5 ) 大谷知行：テラヘルツ波新産業, 斗内政吉監修, ジーシーエム 出版, 大阪, p.149 (2011)

7 ）高柳 順, 大竹秀幸：色材協会誌， 85，459（2012）

8 ）永妻忠夫：テラヘルツ波新産業, 斗内政吉監修, ジーシーエム 出版，大阪，p.238 (2011)

9 ）萩行正憲：テラヘルツ波の基礎と応用，西澤潤一編著，工業調 查会, 東京, p.231 (2005) 